\title{
IBLIS DALAM PERSPEKTIF TEOLOGI SAYYID QUṬB
}

\author{
Norjenah \\ MIS BABUSSALAM Kumai, Kotawaringin Barat \\ Kalimantan Tengah \\ e-mail: acilnorjenah@yahoo.co.id
}

\begin{abstract}
The Devil isthe cause ofthe fall of man to the earth. He had got Adam and Eve in paradise into eating the forbidden fruit, although God had warned them both to not approach the forbidden tree. The attempt of Devil remove them is due to their reluctance prostrate to Adam even though the command of God. Devil disobey God and considers himself betterthan Adam. Defiance against the theologians have their own interpretation, including Sayyid Quț. This article will explore the deeper thinking about the devil Sayyid Quțb.
\end{abstract}

Abstrak: Iblis adalah penyebab jatuhnya manusia ke bumi. Ia telah memperdaya Adam dan Hawa di surga agar memakan buah terlarang, meskipun Tuhan sudah mengingatkan mereka berdua untuk tidak mendekati pohon terlarang tersebut. Usaha Iblis untuk mengeluarkan mereka ini disebabkan oleh keengganan mereka bersujud kepada Adam meskipun itu perintah dari Tuhan.Iblis membangkang perintah Tuhan dan menganggap dirinya lebih baik dari Adam.Terhadap pembangkangan para teolog mempunyai interpretasi sendirisendiri, termasuk di dalamnya Sayyid Quțb. Artikel ini akan mengeksplorasi lebih dalam pemikiran Sayyid Quțb mengenai Iblis.

Keywords:Iblis, setan, sujud, teolog, malaikat, surga.

\section{A. Pendahuluan}

Agama Islam didasarkan pada firman Allah yang diwahyukan, yaitu al-Quran; di sini, dalam sumber bagi seluruh kesalehan Muslim, orang-orang yang beriman akan menemukan, barangkali untuk pertama kalinya, figur setan menurut Islam, yaitu Iblis. ${ }^{1}$ Iblis, setan,

TEOLOGIA, VOLUME 25, NOMOR 2, JULI-DESEMBER 2014 
NORJENAH: Iblis dalam Perspektif Teologi Sayyid Quțb

umumnya terima sebagai salah satu Malaikat, ${ }^{2}$ tetapi menurut penjelasan al-Quran ia menjadi makhluk terbuat dari api. Dalam alQuran ia disebutkan khususnya dalam hubungannya dengan penciptaan Adam, ${ }^{3}$ ketika malaikat mematuhi perintah Tuhan untuk bersujud kepada Adam. Iblis, karena kebanggaan sebagai makhluk yang diciptakan dari api, menolak untuk bersujud kepada makhluk yang terbuat dari tanah, dan dikutuk oleh Tuhan. Akhirnya, ia merayu Adam dan Hawa untuk memakan buah terlarang, dan karena itu mereka berdua akhirnya dikeluarkan dari surga. ${ }^{4}$ Dari kisah sederhana dalam al-Quran ini, tradisi telah mengumpulkan banyak informasi tentang setan, dan masalah kejahatan, aspek yang berbeda dari Iblis, telah mengilhami tidak terhitung cerita dan legenda dalam literature teologi Islam dan mistik. ${ }^{5}$

Iblis, dalam Jāvidnāma-nya Muhammad Iqbal, diperlihatkan sebagai penganut monotheisme yang sebenarnya, seorang malaikat yang dibuang, yang pernah menggoda manusia dan telah menyebabkan manusia diturunkan ke "dunia nyata yang sebenarnya", yang juga berarti bahwa Iblis telah memberi manusia kesempatan untuk memilih antara yang baik dan yang buruk, dan kesempatan untuk berkembang menjadi dewasa dalam masa perjuangan yang lama. ${ }^{6}$ Berdasarkan uraian di atas, artikel ini akan mengeksplorasi lebih lanjut pandangan Sayyid Quṭb mengenai status Iblis tersebut.

\section{B. Sekilas tentang Sayyid Quțb}

Sayyid Quṭb hidup di Mesir selama suatu periode ketika perbedaan pikiran dan debat di bawah kerajaan tunduk kepada monolog Nasserisme. Tahun-tahun formatifhya menyaksikan pergantian gerakan untuk bebas dari kendali Inggris, dan juga debat dan konflik di kalangan orang Mesir sendiri mengenai masa depan negeri mereka. 
Lahir pada 1906 dalam keluarga menengah di dusun Mesir.Quṭb pindah ke Kairo pada 1920-an untuk menyelesaikan pendidikannya. Akhirnya dia jadi guru dan inspektur pada Kementerian Pendidikan, menjadi pegawai di sana sampai dia mengundurkan diri pada 1953. Pada saat yang sama, dia terkenal sebagai penulis dan kritikus sastra, di bawah bimbingan dan pengaruh tokoh seperti 'Abbās al-'Aqqad. Meski sebagai partisipan aktif yang minor dalam kalangan sastra di Kairo selama 1930-an dan 1940-an, Quṭb juga terlibat dalam berbagai debat pada waktu itu. ${ }^{7}$

Karya Sayyid Quțb yang paling monumental adalah FīZilāl alQur'ān (Di bawah Naungan al-Quran).Karya ini memperoleh popularitas yang luas di dunia Islam, dari Maroko sampai Filipina, bahkan di Indonesia menjadi salah satu rujukan penting.Dalam pengertian yang sesungguhnya, karya ini merupakan kitab Tafsìr alIkhwān, dan, secara otoritatif, menempati tataran yang sejajar dengan Tafsīr al-Manār.Selain itu, karya tersebut merupakan dokumen pribadi yang digarap secara intens, ditambah lagi oleh keberadaan Quṭb sebagai seorang syahīd di kalangan al-lkhwān.Ia ditangkap pada 1954, tak lama sesudah Nasser berkuasa di Mesir, dianiaya, dan digantung pada $1966 .^{8}$

Latar belakang kehidupan Quṭb sangat penting untuk kita ketahui.Ia dibesarkan di luar tradisi keagamaan (religious tradition) dan mendapatkan pendidikan di Dār al-'Ulūm; ia cenderung memilih karir sebagai seorang sastrawan, dan sahabat dari tokoh-tokoh seperti 'Aqqad, al-Ḥākim, dan Thaha Husayn. Karya pertamanya tentang al-Quran, al-Tașwìr al-Fann fial-Qur'ān (Gambaran Artistik dalam al-Quran), diterbitkan pada 1945, tapi lebih merupakan sebuah karya untuk dijadikan bahan literatur yang diilhami oleh daya tarik estetika ketimbang sebuah komitmen kepada ajaran agama.Ia adalah seorang patriot Mesir, aktif dalam Wafd. Pada 1949, ia meninggalkan Mesir untuk belajar selama dua tahun di Amerika, mungkin sebagai sebentuk pengasingan secara halus. Barangkali 
NORJENAH: Iblis dalam Perspektif Teologi Sayyid Quțb

saat-saat terakhir ia berada di Amerika, dalam perjalanan pulang, atau setelah ia tiba kembali di Mesir, Quṭb menganut visi Islam alIkhwān. ${ }^{9}$

Ia menjadi seorang aktivis gerakan tersebut dan memimpin Lembaga Dakwah. Ia juga ikut dalam revolusi Juli 1952 setelah mengadakan kontak dengan Nasser dan Anwar Sadat, dan berhubungan dengan beberapa perwira militer. Nasser mendesaknya ikut bergabung dalam Kelompok Pembebasan yang pada 1953 berusaha menggantikan semua partai politik yang lain. Ia menolak. Alasan penolakan dan pemutusan hubungannya dengan Nasser tidak menjadi fokus tulisan ini.Namun, yang jelas, semua itu berasal dari keyakinannya yang tak tergoyahkan tentang makna dan peran Islam serta hakikat kenegaraan.Pan-Arabisme dan sosialisme yang dikampanyekan Nasser, menurut Quțb, adalah bentuk sekularisme yang telah merajalela.

Melihat pengaruh al-Ikhwān yang besar di Mesir ketika Nasser naik ke tampuk kekuasaan, maka tak pelak lagi-sesudah gagal memperoleh dukungan darinya-Nasser memandangnya sebagai musuh besar yang potensial. Setelah lewat beberapa dekade, ketika ideologi dan peran Nasser di pentas dunia mulai berkembang karena beberapa peristiwa seperti perang 1956, pembentukan dan kehancuran Republik Persatuan Arab dan petualangan Yaman Selatan, maka al-Ikhwān pun lantas mulai dianggap sebagai ancaman yang sedang tumbuh. Jika Quṭb pada waktu itu sudah memandang Nasser sebagai penjelmaan lain dari Ibi,is dan pengkhianat Islam, maka Nasser pun memandang Quṭb sebagai seorang fanatik yang berbahaya.

Peristiwa yang paling menentukan dalam perkembangan karir Qutb adalah kunjungannya ke Amerika. Banyak sekali yang dilihat Quṭb di sana-yang diidentifikasikannya sebagai budaya khas Barat yang secara umum tidak Islami, yakni budaya jahīliyah-telah menimbulkan reaksi keras dalam dirinya dan mengubah 
pandangannya tentang Barat. Di dalam salah satu bagian otobiografis dalam bukunya, al-Ma'ālim fial-Ṭarì (Rambu-Rambu Sepanjang Jalan), Quțb memberikan beberapa catatan ihwal implikasi dari perubahan pandangannya dan apa yang dilihatnya di Amerika yang telah menimbulkan kebenciannya. Tentang pengalamannya di Amerika, Quṭb menulis:

Kita, yakni orang-orang Muslim yang ada di Amerika selama beberapa tahun saya berada di sana, adalah kelompok minoritas. Sementara ada kaum sebagai Muslim, sayajustru bersikap sebaliknya.Saya menentang Jahiliyah Barat modern itu dengan sikap keberagamaannya yang tidakjelas dan situasi sosial, ekonomi, dan moralnya yang menimbulkan malapetaka. ${ }^{10}$

Ia memandang teologi Kristen menjijikkan. Konsep-konsep seperti trinitas, dosa warisan atau turunan, serta penebusan dosamenurut hematnya-seluruhnya bertentangan dengan kebenaran, akal, dan hati nurani. Pengumpulan harta kekayaan dalam sistem kapitalisme, monopoli, dan riba yang dilihatnya di sana sungguh sangat mengerikan. Serakah, semuanya serakah...! Demikian pula, individualisme egoistik telah menghalangi solidaritas spontan untuk mencapai solidaritas yang ditetapkan oleh hukum.Dia membenci kebebasan liar yang memungkinan bercampurbautnya laki-laki dan perempuan tanpa batas.Ia berbicara tentang pasar budak yang bernama "emansipasi wanita", tentang kelicikan-kelicikan dan kebobrokan sistem perkawinan dan perceraian yang sangat bertentangan dengan kehidupan natural atau alami! Diskriminasi rasial ini sudah sangat kuat dan ganas. Padahal, betapa logisnya ajaran Islam, betapa mulianya pandangan hidup kaum Muslim, dan betapa tingginya nilai kemanusiaan dalam agama Islam. ${ }^{3}$ Dalam hal ini, penjelasan dan justifikasi Quțb tentang Islam melampaui model pencerahan yang khas di kalangan gerakan reformis yang diwakili oleh kelompok al-Manār. Pengalamannya selama berada di Amerika telah meyakinkan Quṭb: 
NORJENAH: Iblis dalam Perspektif Teologi Sayyid Quțb

bahwa Islam harus memegang kekuasaan merupakan hal yang esensial, demi merealisasikan Islam itu sendiri dan menciptakan masyarakat yang adil dan makmur... Islamlah yang mesti memberikan perintah. Islam ideal sama sekali tidak akan bisa diwujudkanjika Islam itu sendiri tidak punya otoritas apa pun atas kehidupan ini. Islam hams bisa memberikan jalan alternatif kepada kemanusiaan agar ia bisa menemukan idealnya-suatu ideal yang tidak bakal bisa diraih oleh Komunisme, Sosialisme, dan Kristen. ${ }^{11}$

Oleh karena itu, ia sangat mencela kecenderungan orang-orang Mesir kelas menengah yang mencoba berpaling ke Barat. Kita pun, karena kebodohan dan tidak punya tanggung jawab, telah melakukan hal yang sama kepada Islam. Bukan lantaran Islam tidak mempunyai aturan-aturan yang memberitahu kita dan mengatur kehidupan, tetapi lantaran kita, dengan mental budak dan sikap hidup seperti monyet, telah menginginkan Mesir menjadi bagian dari Eropa. Dan karena Eropa dikuasai oleh hukum sekular, bukan hukum agama, maka kitajuga telah melakukan hal yang sama.

\section{Makna Pembangkangan Iblis}

Ketika Tuhan memerintahkan kepada para malaikat untuk bersujud kepada Adam, mereka semua bersujud kecuali Iblis.Ia membangkang dan menolak bersujud kepada Adam. Pertanyaannya: mengapa Iblis tidak mau bersujud?

Secara kebahasaan, sujud berarti tunduk dan mengikuti, ${ }^{12}$ membungkuk dengan khidmat. ${ }^{13}$ Bisa juga diartikan dengan altazallul artinya merendahkan diri dan al-khudu'artinya, ketundukan.Diantara tanda yang paling kuat tentang sujud ialah meletakkan kening di tanah.Ini biasanya dilakukan untuk menghormat raja ketika datang seperti sujudnya Ya'qub dan putraputranya kepada Yusuf. ${ }^{14}$ 
Dalam Islam sujud diartikan dengan meletakkan kening dengan niat beribadah. ${ }^{15}$ Sujud ibadah ini hanya kepada Allah semata. Sujud ibadah ini ada dua macam: pertama, sujudnya makhluk untuk beribadah dengan cara yang sudah ditentukan syara'. Kedua, sujudnya makhluk lain dengan jalan ikut dan tunduk kepada ketetapan-Nya ${ }^{16}$ sebagaimana disebutkan dalam al-Quran: "Dan tumbuh-tumbuhan dan pohon-pohonan kedua-duanya tunduk kepada-Nya" (QS. al-Raḥmān [55]: 6).

Kontroversi mengenai sujudnya malaikat kepada Adam menimbulkan tiga pendapat, yaitu: pertama, sujudnya malaikat kepada Adam sebagai sujud ibadah kepadanya. Pendapat ini dibantah oleh al-Farra. ${ }^{17} \mathrm{Kedua}$, sujud malaikat hanya kepada Allah, sedangkan Adam hanya dijadikan sebagai kiblat.Seperti sujudnya umat Islam saat sholat, berkiblat ke Ka'bah.Sebagaimana disabdakan Nabi, Ka'bah sebagai rumah suci dan kesanalah umat Islam apabila shalat menghadap. ${ }^{18}$ Karena pada hakekatnya yang disembah hanyalah Allah semata.Ketiga, sujud malaikat sebagai penghormatan kepada Adam bukan sujud ibadah.Ibn Taimiyah berpendapat bahwa sujud ini dilakukan atas nama ibadah kepada Allah, bukan ibadah kepada Adam, karena sujud ini dilakukan atas perintah Allah sebagai penghormatan (ta'zim) kepada Adam.Adapun sujud yang dilakukan saudara-saudara Yusuf adalah upacara selamat (tahiyah). ${ }^{19}$

Disamping penghormatan kepada Adam, sujud ini sebagai pertanda atas kelebihan-kelebihan yang dimiliki oleh Adam.Sujud tersebut merupakan ketaatan mutlak kepada Allah,, ${ }^{20}$ atau perintah sujud tersebut sebagai bukti pengakuan (kepada Adam) bahwa manusia lebih unggul dari malaikat.Adam diberi kelebihan berupa akal yang mampu menyerap ilmu pengetahuan, sehingga manusia (selain merusak), juga mampu memakmurkan bumi, yang tidak mungkin dilaksanakan malaikat.Berkaitan dengan ini, Sayyid Quțbmenyatakan bahwa sujud malaikat kepada Adam adalah 
NORJENAH: Iblis dalam Perspektif Teologi Sayyid Quțb

sebagai penghormatan kepada manusia yang dipersiapkan Allah sebagai khalifah dibumi. Quṭb menulis:

Sujudnya malaikat kepada manusia sebagai pertanda kehormatan yang diberikan Allah kepada makhluk yang akan berbuat kerusakan dan menumpahkan darah dibumi. Tetapi manusia masih diberi kelebihannya yang menjadikannya lebih tinggi dari malaikat.Allah memberikan kelebihan kepada manusia berupa rahasia pengetahuan dan kehendak bebas untuk menentukan sendiri jalan hidupnya dan memperkokoh keimanan kepada Tuhan melalui usahanya sendiri dengan bimbingan-Nya, merupakan sebagian dari berbagai rahasia yang berkenaan dengan kelebihannya.Karena itu para malaikat bersujud atas perintah-Nya Yang Maha Agung. ${ }^{21}$

Dengan demikian, Quțb tidak menganggap sujud malaikat merupakan sujud ibadah. Iamemahaminya sebagai rasa hormat kepada Adam. Karena itu, sujudnya malaikat termasuk sujud kepatuhan makhluk ini kepada Tuhan-Nya. ${ }^{22}$ Dari ketaatan malaikat ini justru muncul penciptaan jahat (personifikasi sebagai Iblis).Ia mendurhakai Tuhannya, pembangkang terhadap keagungan Ilahi, merasa bangga dalam berbuat dosa sehingga tertutuplah ia untuk bisa mengenal Tuhan-Nya. ${ }^{23}$ Apa yang dilakukan Iblis ini, tegas Quṭb, karena sifat hasūd yang melekat pada diri Iblis sehingga ia enggan bersujud kepada manusia. ${ }^{24}$

Pembangkangan yang dilakukan Iblis ini kemudian menimbulkan perdebatan panjang di kalangan ulama dan pertanyaan yang muncul adalah siapakah Iblis. Apakah ia termasuk malaikat atau jin. Setidak-tidaknya ada dua pendapat yang menonjol: (1) Iblis termasuk golongan malaikat ${ }^{25}$ dan (2) Iblis termasuk golongan jin.Yang kedua ini berargumentasi bahwa Iblis termasuk golongan jin, karena ia dari bangsa jin, sebagaimana Adam, bangsa manusia. Iblis diciptakan dari api sebagaimana malaikat dari $n u \bar{r}{ }^{26}$ Disebutkan bahwa Iblis pada awalnya pernah berada di kalangan malaikat, bergaul dengan mereka dan mempunyai sifat- 
NORJENAH: Iblis dalam Perspektif Teologi Sayyid Quțb

sifat seperti mereka sehingga seakan-akan ia menjadi bagian dari malaikat. $^{27}$

Menghadapi perdebatan diatas, Quṭb tampaknya tidak mau terjebak dalam perdebatan panjang mengenai siapa Iblis. Menurutnya, Iblis bukan termasuk malaikat. Ia hanya hadir bersama mereka. Seandainya ia malaikat, tentunya ia tidak akan berbuat maksiat. Malaikat adalah makhluk ciptaan Tuhan yang hanya diberi sifat taat mutlak ${ }^{28}$ dan sifat tersebut merupakan tabiatnya. ${ }^{29}$ Allah menciptakan makhluk ini sudah ditentukan tugasnya, termasuk kekhususan yang dimilikinya, dan taat merupakan sifat malaikat yang utama. ${ }^{30}$ Ia bersujud kepada Adam dengan penuh ketaatan dan tidak ada pikiran untuk membangkang (istakbara) dan berbuat maksiat. ${ }^{31}$ Quṭb mengutipkan firman Allah: Mereka para malaikat yang kasar, yang keras, yang tidak mendurhakai Allah terhadap apa yang diperintahkan-Nya kepada mereka dan selalu mengerjakan apa yang diperintahkan"(QS. al-Tahrim [66]: 6).Untuk lebih mempertegas pendapatnya bahwa iblis bukan termasuk golongan malaikat ialah adanya lafaz pengecualian (istiśn $\bar{a}$ ). ${ }^{32}$ Iblis hanya hadir dan berbaur dengan malaikat sehingga mirip mereka. ${ }^{33}$

Untuk lebih meyakinkan lagi bahwa Iblis bukan golongan malaikat, berdasarkan keterangan al-Quran Iblis adalah golongan jin. Jin tercipta dari api atau api yang sangat panas (nār al-samūm). ${ }^{34}$ Adanya petunjuk al-Quran sudah cukup membuktikan bahwa Iblis bukan malaikat, termasuk adanya pembangkangan menunjukkan bahwa perintah sujud bukan saja tertuju kepada malaikat semata. Munculnya Iblis secara person sebagai deklarator pembangkang merupakan awal dari pertempuran antara sifat jahat pada diri Iblis dan manusia yang dipersiapkan Allah sebagai khalifah di bumi.Quṭbmengatakan:

Dari pembangkangan ini sekarang mulailah terungkap suatu medan pertempuran abadi, pertempuran antara ciptaan jahat (yang ada pada) iblis dan (manusia yang dipersiapkan sebagai) khalifah Allah

TEOLOGIA, VOLUME 25, NOMOR 2, JULI-DESEMBER 2014 
NORJENAH: Iblis dalam Perspektif Teologi Sayyid Quțb

dibumi. Maka jadilah pertempuran abadi itu dalam sanubari insan (al-ma'rakah al-khālifah fi damīr al-insān) yaitu pertempuran (dengan penuh perjuangan) untuk mencapai kemenangan dalam kebaikan, dalam pengertian bila manusia mencari perlindungan kepada Tuhannya dan kezhaliman akan berjalan dalam pengertian bila manusia menyerah kepada nafsunya dan berjalan sesat pada Tuhannya. 35 Pertempuran itu akan abadi dan terus berlanjut hingga kehidupan manusia berakhir di bumi. ${ }^{36}$

Sementara itu mengenai larangan Adam mendekati sebuah pohon para mufassir banyak sepakat mengenai pohon yang dimaksud dalam ayat tersebut, Quțb berpendapat bahwa Adam dan istrinya dilarang memakan buah dari sebuah pohon di taman. Ini merupakan perlambang atas apa yang dilarang, yang memang perlu bagi manusia di bumi. Sebab tanpa larangan, kehendak bebas yang diberikan manusia tidak akan berkembang, termasuk akan sulit membedakan antara manusia dan binatang. Kehendak bebas (tapi terbatas) adalah ciri khas manusia dan manusia yang tidak memilikinya berasal dari dunia binatang tapi dalam wujud manusia. ${ }^{37}$ Di tempat lain QS. Ta Ha ayat 120 Quṭb menafsirkan ayat tersebut dengan lebih rinci:

Pohon yang dimaksud adalah lambang sifat dasar manusia, keterbatasan umur manusia, keterbatasan kekuatan manusia.Dari sinilah justru muncul hasrat-hasrat (keinginan) manusia untuk hidup lama, berkuasa dengan lama.Dari dua sisi hasrat ini syaithan masuk.Masuk melalui kelemahan manusia.Ini seperti yang terjadi pada makhluk yang bernama Adam. ${ }^{38}$

Mengenai kalimat Azallahuma, menurut Quṭb syaițān menggelincirkan keduanya (dari taman) adalah kalimat piktorial, menggambarkan gerakan yang bahwa adanya kisah pohon dan larangan yang mendekatinya, semua itu merupakan ujian manusia. Dengan digelincirkannya Adam dari surga merupakan ujian pertama manusia.Kejadian ini, juga sebagai peringatan sekaligus pelajaran bagi manusia. ${ }^{39}$ Sehingga apa yang dilakukan manusia merupakan 
beban dan tanggung jawab yang harus dipikulnya sendiri. Ujian yang datang kepadanya secara kontinyu adalah awal dalam mencapai keberhasilan, termasuk kekuatan untuk menghadapi kesulitan dan keputusasaan adalah perjuangan. ${ }^{40}$

Quțb sampai pada kesimpulannya, siapa Iblis dan malaikat adalah persoalan yang berasal dari tempat yang tersembunyi (alghaib) yang disimpan oleh Allah dan persoalan tersebut hanya Dia yang lebih mengetahui kebenarannya. Manusia tidak akan memperoleh apa-apa jika dapat mengetahuinya. ${ }^{41}$ Karena itu, manusia tidak akan mampu mengetahui hal-hal diluar pengetahuan yang diberikan Allah, sebatas tugasnya sebagai khalifah di bumi. ${ }^{42}$

\section{Akibat Tipu Daya Iblis}

Sebagaimana disebutkan dalam al-Quran, perbuatan Iblis yang membangkang membuatnya dilaknat oleh Tuhan, kemudian disebut oleh al-Quran termasuk golongan kafir. Laknat dan predikat kafir yang diberikan kepadanya tidak membuatnya menyerah.Ia memohon kepada Tuhan agar diberi tangguh kematiannya, termasuk diberinya kebebasan untuk menggoda Adam dan anak cucunya. Permohonan Iblis pun dikabulkan Allah, setelah itu Iblis berkata:

Iblis menjawab, "Karena Engkau telah menghukum saya tersesat, saya benar-benar akan (menghalang-halangi) mereka dari jalan Engkau yang lurus. Kemudian saya akan mendatangi mereka dari muka dan belakang dari kanan dan kiri mereka. Dan Engkau tidak akan mendapati kebanyakan mereka bersyukur (taat)."43

Berdasarakan firman Allah ini, Quṭb menegaskan bahwa ini merupakan awal deklarasi Iblis sebagai musuh manusia hingga waktu yang sudah ditentukan. Namun Quțb tidak merinci bentukstrategi apa yang diterapkan Iblis untuk menyesatkan manusia. Ia hanya menjelaskan bahwa tujuan hidup Iblis adalah memperdaya 
NORJENAH: Iblis dalam Perspektif Teologi Sayyid Quțb

Adam dan keturunannya karena dialah yang menyebabkan dilaknat dan diusir. ${ }^{44}$

Dengan adanya sumpah inilah, menurut Quțb, sebagai dinding pemisah atau pembatas jalan manusia (antara haq dan bāțil). ${ }^{45}$ Dari sumpah ini pula dimulainya pertempuran abadi (al-ma'rakah alkhālidah) manusia dengan iblis. ${ }^{46}$ Iblis dalam bentuk ciptaann jahat (khaliqah al-syarr al-mujassimah) dan manusia sebagai khalifah dibumi. Bumi sebagai medan pertempuran antara keduanya. ${ }^{47}$ Lebih lanjut Qutb menegaskan, walaupun pertempuran itu terjadi di bumi pada hakekatnya pertempuran abadi tersebut terjadi dalam sanubari insan (al-ma'rakah al-khālidah fi ḍamīr al-insān).Quṭb tidak menjelaskan secara rinci bagaimana bentuk peperangan tersebut.Ia hanya menggarisbawahi bahwa peperangan tersebut perang antara kebaikan dan kezaliman. Kebaikan untuk mencapai kemenangan dalam pengertian bila manusia mencari perlindungan kepada Tuhannya dan kezhaliman berjaya, bila manusia menyerah kepada nafsunya dan berjalan sesat dari Tuhannya. ${ }^{48}$ Perwujudan dari peperangan itu adalah jihad.Tetapi sebenarnya keluasan pengertian itu sebenarnya lebih besar dan lebih jauh dari sekedar berperang dengan segala variasinya. ${ }^{49}$ Standarisasi konsepnya ini berdasarkan ayat:"Janganlah kamu merasa hina dan susah, kamu adalah orangorang yang lebih tinggi, kalau sekiranya kamu benar-benar beriman." 50

Dalam pandangan Quțb, ayat diatas melukiskan keadaan abadi yang harus dijalani seorang mukmin, dimana seorang mukmin harus tabah dalam menghadapi apapun, karena perang menurutnya hanyalah salah satu dari sekian banyak jalan untuk mencapai kejayaan yang termuat dalam ajaran Allah. ${ }^{51}$

Untuk menghadang Adam dan keturunannya dari jalan yang lurus (dalam mencapai kemenangan) Iblis berusaha membelokkan, menjauhkan setiap manusia yang berusaha berpegang teguh kepada perintah Allah dan menjauhi larangan-Nya, disaat manusia berusaha 
memperkokoh keyakinan dan ketaatan kepada-Nya.Sebaliknya, iblis menghadangnya dari segala penjuru. ${ }^{52}$

Strategi yang digunakan ialah berusaha memutar balikkan fakta, agar manusia menganggap dibumi ini segala sesuatunya adalah baik, indah dan bagus, yang hakikatnya itu buruk (jelek). ${ }^{53}$ Sebagaimana diungkapkan Quṭb :

"Kebatilan berteriak, suaranya diangkat keras-keras, bulunya beterbangan diirngi oleh fatamorgana buatan yang menipu mata dan penglihatan manusia, sehingga kejelekan dan kezhaliman yang ada dibalik fatamorgana itu tidak engkau lihat." 54

Disinilah kelihaian tipu muslihatnya, sehingga akan terjadi tarik menarik antara iman dan taat kepada Allah pada satu sisi dan pengaruh tipu muslihat iblis pada sisi lain. Karena iblis sendiri tidak akan merasa puas sebelum menyaksikan hidup manusia berubah akibat tipu muslihatnya. ${ }^{55}$ Usahanya akan tampak berhasil bila manusia sudah mengikuti kehendaknya yaitu dengan terealisasinya perbuatan dosa yang dilakukan manusia,, salah satunya ialah bila manusia tidak lagi mensyukuri nikmat Allah dan bahkan manusia sampai pada tahap tidak mengenal lagi siapa Tuhannya. Inilah puncak dari keberhasilan godaan Iblis kepada manusia. ${ }^{56}$ Akhirnya Quțb menegaskan bahwa gambaran manusia yang menerima ajakan Iblis dan berpaling dari melakukan taat kepada Allah adalah manusia yang mengangkat iblis dan turunannya sebagai wali (pemimpin).

Oleh karena itu bagi manusia yang tidak mengindahkan ajakannya adalah jelas musuhnya.Mengenai orang-orang yang selamat dari tipu daya Iblis, sebagaimana disebutkan dalam al-Quran ialah mereka yang tergolong orang-orang yang mukhlaṣ.

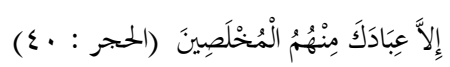

kecuali hamba-hamba-Mu yang mukhlas diantara mereka" (QS. alHijr [15]: 40). 
NORJENAH: Iblis dalam Perspektif Teologi Sayyid Quṭb

Kata Mukhlașin derivasi Arab akhlașa berarti membersihkan, mensucikan, atau menyelamatkan.Tambahan hamzah memberi pengertian transitif.Oleh karena itu, mukhlasin dapat pula diartikan dengan orang-orang yang dibersihkan, disucikan atau diselamatkan. Bila dihubungkan dengan ayat diatas, bahwa orang yang selamat dari godaan Iblis adalah orang yang selalu bersyukur atas nikmat yang diberikan Allah kepadanya. Ditempat lain Allah menegaskan, bahwa orang yang sesat itu cenderung kepada kehidupan dunia, secara harfiah, kepada bumi (akhlada ilā al-arḍ) dan menurutkan hawa nafsunya sehingga tak mau berpegang teguh dengan ayat-ayat Allah.

Mengenai hal ini Quṭb berpendapat, bahwa mukhlisyang dimaksud ialah kemurnian jiwa, pengabdian seorang hamba yang tiada tendensi lain kecuali hanya kepaad Allah. Allahlah yang menjadi tujuan utama pengabdiannya.Kemurnian jiwa adalah salah satu syarat sombong hamba yang tak bisa dikuasai iblis. Lebih lanjut Quṭb menegaskan bahwa orang yang selalu berusaha membersihkan jiwanya niscaya ia akan mampu mengendalikan emosional (nafsu) nya dan ia akan terbebas dari penyakit sombong dan angkuh. Dalam dirinya tidak ada sifat memberontak terhadap Tuhan.Ia merasa cukup dengan dirinya tidak ada sifat memberontak terhadap Tuhan.

Ia merasa cukup dengan apa yang sudah dikaruniakan Allah kepadanya. Jiwa mereka terkunci untuk hal-hal yang dilarang Allah. Mereka juga faham bahwa apa yang dilakukannya selalu terdeteksi oleh-Nya. Inilah yang menjadi landasan keyakinan mereka untuk bisa selalu berhubungan dengan Allah. Terhadap hamba yang demikian iblis tidak mampu menguasainya bahkan sebaliknya, Iblis menghindar darinya. Akhirnya, menurut Quțb bahwa orang yang mukhlis ialah mereka yang jiwanya hanya diserahkan kepada Allah semata. Karena mereka yakin Allah tidak akan meninggalkannya meskipun mereka telah tiada. ${ }^{57}$ Sebagaimana diungkapkan Quṭb :

Keyakinan kepada Allah adalah sumber inspirasi untuk hidup yang tinggi, bersih, suci, terpelihara dan takwa serta suka 
beramal shalih.Terutama pemberitahuannya tentang pahala akhirat dengan suatu balasan atas segala kepayahan dan penderitaan yang dialami di dunia, akan menjadikannya tentram sekalipun ketika dia meninggalkan dunia tidak menyandang pangkat apapun. ${ }^{58}$

Dan mereka itulah hamba Allah yang punya prinsip yaitu selalu berusaha taat dan patuh kepada perintah-Nya. Oleh karena itu, Iblis tidak mampu menguasai mereka, ini sesuai dengan apa yang menjadi kehendak dan takdir-Nya, mereka selamat dari tipu daya iblis, sesuai dengan janji Allah. ${ }^{59}$ Sebagaimana firman-Nya :

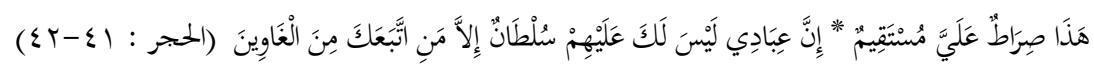

Ini adalah jalan lurus, kewajiban Akulah (menjaganya). Sesungguhnya hamba-hamba-Ku tidak ada kekuasaan bagimu terhadap mereka, kecuali orang yang mengikut kamu, yaitu orang-orang yang sesat. ${ }^{60}$

Ayat diatas untuk meyakinkan bahwa jalan tersebut benar adanya, merupakan jalan yang diridloi dan kehendak Allah, berisi undang-undang, hukum, yang dengannya orang akan mendapat petunjuk ataupun ia tersesat. ${ }^{61} \mathrm{Hal}$ ini sudah merupakan kehendak dan taqdir-Nya, apakah ia binasa ataukah selamat dari ancaman Tuhan kelak, karena memang sudah merupakan janji-Nya terhadap seluruh anak Adam. ${ }^{62}$ Sebagaimana firman-Nya :

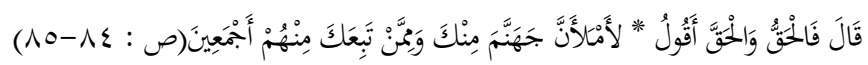

Maka yang benar (adalah sumpah-Ku) dan hanya kebenaran itulah yang kukatakan.Sesungguhnya Aku pasti akan memusuhi neraka jahanam dengan jenis kamu dan dengan orang-orang yang mengikuti kamu diantara mereka semuanya. ${ }^{63}$

\section{Eksistensi Iblis}

Kata Iblis muncul dalam al-Quran berkaitan dengan kisah tentang Adam sebagai bapak manusia pertama. ${ }^{64}$ Ketika Allah hendak 
NORJENAH: Iblis dalam Perspektif Teologi Sayyid Quțb

menciptakan Adam sebagai khalifah dibumi para malaikat mengakui keunggulan Adam. Setelah itu Allah menyuruhnya untuk bersujud, merekapun bersujud kecuali diantara mereka yang disebut al-Quran dari golongan jin ${ }^{65}$ bernama Iblis.

Mengenai peran Iblis atas kesesatan manusia tidak ada penjelasan yang jelas. Setelah terjadi pembangkangan, Iblis hanya membuat statemen bahwa ia akan menggoda dan menyesatkan Adam serta anak cucunya. Pada kisah ini, ada dua sifat yang saling bertolak belakang yang disebut al-Quran dengan malaikat dan iblis.Kedua sifat tersebut dimunculkan oleh dua makhluk rohani yang masih mempunyai hubungan dengan kejiwaan manusia.Bagaimana mengenai sifat hubungan antara keduanya, dengan manusia tidaklah jelas diketahui dengan pasti.

Kontradiksi dua sifat tersebut berpengaruh besar terhadap manusia yang disiapkan untuk taat dan patuh.Kedurhakaan Iblis ini mengandung adanya pertentangan antara haq dan bāțil, melahirkan garis tipis yang memisahkan antara ketaatan pada Allah dan kebebasan manusia untuk memilih tindakannya.Sementara Quṭb menganggap bahwa akal merupakan kekuatan jiwa manusia yang tidak tampak kegiatannya.Ini hanya dapat diidentifikasi melalui perasaan dan pengalaman.Namun, di dalam jiwa tersebut sering terjadi pertentangan atau tarik menarik antara dua dorongan.Dua dorongan itu salah satunya mengarah kepada tindakan yang dibenarkan Tuhan yang biasa disebut dengan sifat baik menurut ajaran al-Qur'an. Jenis sifat ini oleh Quṭb disebut dengan sifat malaikat, disamping dorongan diatas tersebut, ada pula dorongan kebathilan yang menimbulkan tindakan menyimpang dari ajaran Tuhan, didefinisikan Quțb sebagai sifat iblis, dimana sarana jahat melekat kepadanya. ${ }^{66} \mathrm{Pada}$ tahap memilih inilah antara dorongan malaikat dan iblis saling mengambil peran.Tentunya, salah satu dari dua kekuatan ini berusaha menuntun kepada jalan kebenaran dan kebaikan. 
Sedangkan, keingkaran kepada Tuhan merupakan kekuatan iblis yang ada pada manusia.Dua kekuatan itu jelas saling bertentangan dalam diri manusia dan saling mengalahkan, yang disebut oleh Quțb sebagai al-ma'rakah al-khālidahfi ḍāmīr al-insān (pertempuran abadi dalam sanubari manusia). ${ }^{67}$

Menurut Quțb, ketika Iblis menggelincirkan Adam dan istrinya dari surga, maka mulailah suatu pertempuran baru ditempat yang ditetapkan Allah antara manusia dan syaithan yang akan berlangsung sampai akhir zaman. Pertempuran itu akan berlangsung bebas tanpa henti. Sementara manusia bukanlah sebangsa malaikat.Dia tidak selalu taat, tunduk dan menyerah, tetapi juga tidak selalu jahat, membangkang dan sesat.Keingkaran pada Tuhan merupakan realisasi dari kebebasan manusia yang tidak mampu mengendalikan hawa nafsunya. 68

Quṭb juga mengungkapkan pentingnya memerangi hawa nafsu yang berada pada manusia. Hal ini dapat dilacak dari pendapat singkatnya, yaitu:

"Pertempuran itu merupakan pertempuran yang mendasar yaitu pertempuran antara mengikuti hawa nafsu (keinginan / kehendak) dan mengikuti petunjuk Tuhan.Pertempuran dengan syahwat dalam mengekang kehendak bebas manusia." 69

Selanjutnya Quṭb menegaskan bahwa pertempuran tersebut berlangsung dalam sanubari manusia.

"Pertempuran tersebut berlangsung dalam sanubari (manusia), dan dalam hidup manusia.Pertempuran tersebut akan terus berlangsung dan tidak akan ada putusnya."70

Akhirnya Quțb berpendapat, yang dimaksud perang dengan iblis ialah peperangan melawan dirinya sendiri.71

Demikian gambaran bentuk peperangan manusia yang berperang melawan nafsu dan syahwatnya.72Dan dalam pertempuran-pertempuran itu, manusiapun kadang dikuasai oleh 
NORJENAH: Iblis dalam Perspektif Teologi Sayyid Quțb

kelemahannya, kecenderungannya, nafsunya dan keinginannya, termasuk kebodohannya. ${ }^{73}$

Dalam kondisi seperti itu, manusia lupa akan potensinya. Inilah yang dialami oleh Adam dan istrinya, dimana saat itu Adam mulai terbius dan melupakan janjinya. ${ }^{74}$

Kekalahan manusia akan dapat dilihat, bila ia terlena dan tidak sadar bahwa dirinya sudah terjermus kedalam perbuatan dosa. Sebagaimana pernyataan Quṭb :

"Manusia tenggelam dalam syahwatnya yang terus meluncur, tetapi ia akan melanjutkan langkahnya yang salah tersebut. Akhirnya, bergumul dengan Lumpur dan tanah liat.Berdasarkan keyakinannya bahwa dengan melakukan perbuatan seperti itu hidupnya akan senang dan terlepas dari belenggu."75

Ini berarti bahwa ketersembunyian iblis berada dalam suatu tempat dalam diri manusia yang tak diketahui oleh pemiliknya yaitu manusia.Ia dapat membisikkan sesuatu kepada diri (manusia) sendiri, yang ternyata itu merupakan bisikan dari lubuk yang paling dalam. Dari sini, sebenarnya manusia pada awal sejarahnya sudah tahu cara-cara untuk mencapai kemenangan apabila dikehendakinya dan takluk apabila ia menyukai kekalahannya sendiri. ${ }^{76}$

Ketika Adam dan istrinya melanggar janji kemudian diperintah Allah agar turun ke bumi, Quțbmengungkapkan:

"Dan pertempuran abadi itu berpindah ke lapangan yang asli (shahih), yang akan berlangsung bebas tanpa henti.Pertempuran antara janji Allah dan tipu daya syaithan, iman dan kekafiran, haq dan bathil, petunjuk dan kesesatan.Manusia bertempuran melawan dirinya sendiri dalam bentuk usaha untuk memperoleh kemenangan atau merugi." 77

Sarana yang dipergunakan Iblis dalam menyesatkan manusia ialah syahwat.Pada akhir pembahasan, Quț menegaskan bagaimana langkah konkrit iblis untuk bisa masuk pada jiwa manusia melalui 
sarana syahwat yang ada, hanya Allah yang lebih mengetahui. ${ }^{78}$ Tentunya, ada solusi yang ditawarkan Quṭb untuk menangkal segala sesuatu yang menyesatkan manusia yaitu apabila manusia berbuat salah atau berbuat dosa maka bersegeralah mohon ampunan dan maghfiroh-Nya. Sebagaimana diungkapkannya :

"Adam bangkit dari kedudukan rendahnya, mengalahkan watak alaminya, sehingga ampunan Tuhan senantiasa tiba jika ia menghadap dan berlindung kepada-Nya." 79

Tentunya, dari pembahasan diatas penulis dapat mengidentifikasi eksistensi iblis saat ini dalam pandangan Quț, yaitu iblis yang bersemayam dalam sanubari manusia dan realnya adalah apabila kebaikan terkalahkan oleh kezhaliman dimana manusia menyerah kepada nafsunya dan berjalan sesat dari Tuhannya.Lebih lanjut Quṭb menegaskan bahwa setiap individu bertanggung jawab untuk membersihkan dan mensucikan jiwanya, untuk mencegahnya dari keinginan hawa nafsu ketika mendekati jurang bahaya.Ajaran Tuhan menetapkan bahwa jiwa itu mempunyai potensi untuk menjadi jahat dan menjadi baik.Tugas pemiliknya adalah untuk memberikan jalan, dan memikul tanggung jawab dari pikirannya itu. ${ }^{80} \mathrm{Hal}$ ini berdasarkan firman-Nya :

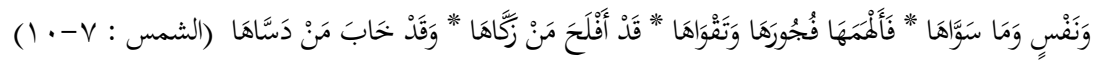

Dan jiwa serta penyempurnaan (ciptaannya), maka Allah mengilhamkan kepada jiwa itu (jalan) kefasikan dan ketakwaannya, sesungguhnya beruntunglah orang yang mensucikan jiwa itu, dan sesungguhnya merugilah orang yang mengotorinya. (QS. al-Syams [91]: 7-10).

\section{Penutup}

Allah memberikan kebebasan kepada manusia untuk mencari kesenangan bagi dirinya, namun dalam batas-batas yang tidak menghancurkan fitrahnya.Sebagai imbalan dari kebebasan memilih, Allah telah menetapkan bahwa setiap manusia mempunyai tanggung 
NORJENAH: Iblis dalam Perspektif Teologi Sayyid Quțb

jawabnya sendiri.Oleh karena itu manusia bertanggung jawab terhadap kebaikan dan kejahatan yang diusahakan untuk dirinya.

Manusia telah dimuliakan Allah dan kemulian ini tidak akan dapat disempurnakan olehnya selain dengan mewujudkan sifat kemanusiaan itu. Karena itulah, ia wajib melawan kejahatan, kebinasaan dan kekejian dalam semua tempat persembunyian, termasuk memerangi hawa nafsu yang ada dalam jiwanya. ${ }^{81}$

Untuk merealisasikan itu, agar tidak salah jalan maka manusia punya sandaran.Sandaran itu ialah akidah.Akidah adalah tongkat, yang membimbing umat manusia dengan petunjuk-Nya dari jalan hidup yang berbelok-belok dan panjang. Akidah merupakan sebuah risalah yang terbit dari kedalaman hati nurani, yang menyatakan perasaan dan menjadikan indra berkelip-kelip dengan megahnya. Akidah harus ada karena kekuatan kata-kata adalah sebagai sarana penterjemah dari akidah.Ia membuat jiwa manusia menjadi hidup, sehingga mampu memberikan kehidupan kepada manusia itu , dan hanya satu sandaran akidah terhadap Allah. ${ }^{82}$

Dari uraian diatas, penulis menyimpulkan bahwa pandangan Quṭb mengenai eksistensi Iblis adalah sebagai yang bersemayam dalam jiwa manusia.Mempengaruhi manusia dengan berusaha mengendalikan nafsu syahwat, tentunya dalam jiwa tersebut tersimpan potensi manusia. Keberhasilan manusia itu akan tercapai apabila ia berpegang teguh kepada akidah, dan akidah yang benar adalah kepada Allah. Dengan mematuhi segala tuntunannya, akhirnya sentral utama dari semua itu adalah bagaimana ia bisa mengendalikan hawa nafsu (syahwat)nya. [

\section{Catatan Akhir}


1Peter J. Awn, Tragedi Setan: Iblis Dalam Psikologi Sufi, terj. Arif Rakhmat, Yogyakarta: Bentang Budaya, 2000, h. 39.

${ }^{2}$ Abdullah Yusuf Ali, Qur'an: Terjemahan dan Tafsirnya, Juz I-XV, terj. Ali Audah, Jakarta: Pustaka Firdaus, 1993, h. 25.

${ }^{3}$ QS. al-Baqarah [2]: 34; al-A'rāf [7]: 10; al-Hijr [15]: 31; al-Isrā' [17]: 63; al-Kahfi [18]: 48; Ṭā Hā [20]: 115; al-Ahzzab [33]: 74.

${ }^{4}$ Annemarie Schimmel, Sayap Jibril: Gagasan Religius Muhammad Iqbal, terj. Shohifullah, Yogyakarta: Lazuari, 2003, h. 266.

5Ibid.

${ }^{6}$ Annemarie Schimmel, "Kata Pengantar" untuk buku Peter J. Awn, Tragedi Setan: Iblis Dalam Psikologi Sufi, terj. Arif Rakhmat, Yogyakarta: Bentang Budaya, 2000, h. v.

${ }^{7}$ A. H. Johns, "Bebaskan Kaumku!: Refleksi Sayyid Quthb atas Kisah Nabi Musa Dalam al-Qur'an, Jurnal Studi-studi IslamAl-Hikmah, No. 15 Vol. VI/Tahun 1995, h. 7-9.

${ }^{8}$ Ibid.

${ }^{9}$ Charles Tripp, "Sayyid Quthb: Visi Politik" dalam Ali Rahnema [ed.], Para Perintis Zaman Baru Islam,Bandung: Mizan, 1996, h. 155165.

${ }^{10}$ A. H. Johns, “Bebaskan Kaumku!”, h. 9.

11 Ibid.

${ }^{12}$ Aḥmad Muștafā al-Marāghī, Tafsīr al-Marāghī, Juz I, Beirūt: Dār al-'Ulūm, 1394/1974, h. 85.

${ }^{13}$ Ahmad Warson Munawwir, Kamus al-Munawwir, Yogyakarta: Pustaka Progressif, 1996, h. 610.

${ }^{14}$ Teungku Muhammad Hasbi Ash-Shiddiqi, Tafsir al-Qur'an alMajid, Vol. I, Semarang: Pustaka Rizki Putra, 1996, h. 79.

${ }^{15} \mathrm{Abī}$ al-Faḍl Syihāb al-Dīn Sayyid Maḥmūd al-Alūsī al-Baghdādī,

Tafsīr Rūḥ al-Ma'ānī Tafsìr al-Qur'ān al-'Azịim wa al-Sabu' al-Maśanī, Juz U, Beirūt: al-Turāṡ al-'Arabī, t.th, h. 28.

${ }^{16}$ Aḥmad Mușțafā al-Marāghī, Tafsìr al-Marāghī, Juz I, h. 86.

${ }^{17}$ Hasbi ash-Shiddiqi, Tafsir al-Qur'an al-Majid, Vol.I, h. 79.

18 Muhammad Jamāl al-Dīn al-Qāsimī, Maḥāhasin al-Ta'wil, Juz I,

Beirut: Dār al-Fikr, 1996, h. 101-102.

${ }^{19}$ Hasbi ash-Shiddiqi, Tafsir al-Qur'an al-Majid, Vol.I, h. 79.

${ }^{20}$ Abdullah Yusuf Ali, Qur'an, h. 25.

${ }^{21}$ Sayyid Quṭb, Tafsīr fì Zilāl al-Qur'ān, Jil. I, Beirūt: al-Turāṡ al'Arabī, 1971, h. 28.

22Ibid.

TEOLOGIA, VOLUME 25, NOMOR 2, JULI-DESEMBER 2014 
23Ibid.

24Ibid.,h. 69.

25Jamāl al-Dīn al-Qāsimī, Maḥāhasin, h. 103

26Ibid.

27Muhammad Isa Dawud, Dialog dengan Jin Muslim, terj. Afif Muhammad dan H. Abdul Adhiem, Pustaka Hidayah, Bandung, 1995, h. 61

28 Sayyid Quț, Tafsìr, Jil. III, h. 476.

29Ibid., Jil. V, h. 205

30Ibid

31Ibid., Jil. III, h. 477

${ }^{32}$ Kata illa yang makna aslinya kecuali dan dipakai dalam arti istina $\bar{a}^{\prime}$ (pengecualian), itu kadang-kadang dipakai dalam arti istiśn $\bar{a}^{\prime}$ munqați' (makna aslinya pengecualian yang dipotong), artinya, barang yang dikecualikan itu tak sama jenisnya dengan barang yang disebutkan pertama, sehingga dua barang itu nampak dari jenis yang berlainan, jadi, jika ada ungkapan jaā al-qaumu illā himārān maka ini berarti, orang-orang telah datang, tetapi himar tidak, karena orang dan himar adalah dua jenis makhluk yang berlainan. Maulana Muhammad Ali, Islamologi, terj. R. Kaelan dan H.M. Bachrun, Ichtiar Baru, Jakarta, 1997, h. 129

33 Sayyid Quțb, Tafsìr, Jil. I, h. 68

34Ibid., h. 477

35Ibid., h. 68

36Ibid., h. 69

37Sayyid Quṭb, Tafsïr, Jil.. I, h. 69

38Ibid., Jil. V, h. 500

39Ibid., Jil. I, h. 70

40Ibid., h. 74

${ }^{41}$ Ibid., h. 69-70

42Ibid

[21]:84.

${ }^{43}$ QS. al-A'rāf [7]: 16-17; QS. al-Mā'idah [5]:20, QS. al-Anbiyā'

${ }^{44}$ Sayyid Quțb, Tafsïr, Jil.. III, h. 478

45Ibid., Jil. VII, h. 111

${ }^{46}$ Ibid., Jil. V, h. 206

${ }^{47}$ Ibid., Jil. I, h. 64

${ }^{48}$ Ibid., h. 67

${ }^{49}$ Sayyid Quțb, Petunjuk Sepanjang Jalan, terj. A. Rohman Zainuddin MA, Jakarta: Media Dakwah, 1987, h. 271. 
${ }^{50 Q S . ~ A l i ~ ' I m r a ̄ n ~[3]: ~} 139$.

${ }^{51}$ Sayyid Quțb, Petunjuk, h. 272.

52Sayyid Quț, Tafsìr, Jil. III, h. 478.

53Ibid., Jil.. V, h. 206-207.

${ }^{54}$ Sayyid Quthb, Petunjuk, h. 281.

55 Sayyid Quț, Tafsïr, Jil. III, h. 479.

56Ibid., Jil. V, h. 206.

${ }^{57}$ Sayyid Quțb, Tafsir , Jil. V, h. 207

58Sayyid Quțb, Petunjuk, h. 276

59 Sayyid Quțb, Tafsïr, Jil. VII, h. 111

${ }^{60}$ QS. al-Hijr [15]: 41-42; Sayyid Quțb, Tafsïr, Jil. VII, h. 394.

${ }^{61}$ Sayyid Quțb, Tafsïr, Jil. V, h. 207

62Ibid., Jil. VII, h. 111

${ }^{63}$ QS. Ṣād [38]: 84-85.

${ }^{64}$ Aisyah Abdurahman, Manusia Sensivitas Hermeneutika alQuran, terj. Adib al-Arif, Yogyakarta: LKPSM, 1997, h. 27.

65Fazlur Rahman, Tema Pokok al-Qur'an, terj. Anas Mahyudin, Pustaka, Bandung, 1983, h. 27

66 Sayyid Quțb, Tafsìr, Jil. I, h. 69

67Ibid., h. 68

${ }^{68}$ Sayyid Quthb, Ma'alim, h. $100-101$

${ }^{69}$ Sayyid Quṭb, Tafsirr, Jil. III, h. 491

70Ibid

71Ibid., h. 491- 492

${ }^{72}$ Ibid

${ }^{73}$ Sayyid Quthb, Karakteristik Konsepsi Islam, terj. Muzalim, Pustaka, Jakarta, 1990, h. 112

74 Sayyid Quț, Tafsìr, Jil. I, h. 69

75 Sayyid Quthb, Ma'alim, h. 281

76 Sayyid Quțb, Tafsīr, Jil. I, h. 70

${ }^{77}$ Ibid., h. 70 - 73

78Ibid., Jil. V, h. 208

${ }^{79}$ Ibid., Jil. I, h. 69

${ }^{80}$ Sayyid Quṭb, Beberapa Studi Tentang Islam, terj. A. Rahman Zainuddin MA, Media Dakwah, Jakarta Pusat, Cet II, 1982, h. 82-83

81 Sayyid Quțb, Beberapa,h. 84

82Ibid., h. 179-187.

TEOLOGIA, VOLUME 25, NOMOR 2, JULI-DESEMBER 2014 


\section{DAFTAR PUSTAKA}

Abdurahman, Aisyah, Manusia Sensivitas Hermeneutika al-Quran, terj. Adib al-Arif, Yogyakarta: LKPSM, 1997.

Ali, Abdullah Yusuf, Qur'an: Terjemahan dan Tafsirnya, Juz I-XV, terj. Ali Audah, Jakarta: Pustaka Firdaus, 1993.

Ali, Maulana Muhammad, Islamologi, terj. R. Kaelan dan H.M. Bachrun, Ichtiar Baru, Jakarta, 1997.

Awn, Peter J., Tragedi Setan: Iblis Dalam Psikologi Sufi, terj. Arif Rakhmat, Yogyakarta: Bentang Budaya, 2000.

Baghdādī, Abī al-Faḍl Syihāb al-Dīn Sayyid Maḥmūd al-Alūsī, Tafsīr Rūh al-Ma'ānī Tafsīr al-Qur'ān al-'Azīm wa al-Sabu' al-Maśanī, Juz U, Beirūt: al-Turāś al-'Arabī, t.th.

Dawud, Muhammad Isa, Dialog dengan Jin Muslim, terj. Afif Muhammad dan H. Abdul Adhiem, Pustaka Hidayah, Bandung, 1995.

Hasbi Ash-Shiddiqi, Teungku Muhammad, Tafsir al-Qur'an alMajid, Vol. I, Semarang: Pustaka Rizki Putra, 1996.

Johns, A.H., "Bebaskan Kaumku!: Refleksi Sayyid Quthb atas Kisah Nabi Musa Dalam al-Qur'an, Jurnal Studi-studi IslamAl-Hikmah, No. 15 Vol. VI/Tahun 1995.

Marāghī, Aḥmad Mușțafā Tafsīr al-Marāghī, Juz I, Beirūt: Dār al'Ulūm, 1394/1974.

Munawwir, Ahmad Warson, Kamus al-Munawwir, Yogyakarta: Pustaka Progressif, 1996.

Qāsimī, Muḥammad Jamāl al-Dīn, Maḥāhasin al-Ta'wil, Juz I, Beirut: Dār al-Fikr, 1996.

Quțb, Sayyid, Beberapa Studi Tentang Islam, terj. A. Rahman Zainuddin MA, Jakarta: Media Dakwah, 1982.

Quțb, Sayyid, Petunjuk Sepanjang Jalan, terj. A. Rohman Zainuddin MA, Jakarta: Media Dakwah, 1987.

Quṭb, Sayyid, Tafsīr fỉ Zilāl al-Qur'ān, Jil. I, Beirūt: al-Turāṡ al'Arabī, 1971. 
Quțb, Sayyid, Karakteristik Konsepsi Islam, terj. Muzalim, Pustaka, Jakarta, 1990.

Rahman, Fazlur, Tema Pokok al-Qur'an, terj. Anas Mahyudin, Pustaka, Bandung, 1983.

Schimmel, Annemarie, "Kata Pengantar" untuk buku Peter J. Awn, Tragedi Setan: Iblis Dalam Psikologi Sufi, terj. Arif Rakhmat, Yogyakarta: Bentang Budaya, 2000.

Schimmel, Annemarie, Sayap Jibril: Gagasan Religius Muhammad Iqbal, terj. Shohifullah, Yogyakarta: Lazuari, 2003.

Tripp, Charles, "Sayyid Quthb: Visi Politik" dalam Ali Rahnema [ed.], Para Perintis Zaman Baru Islam,Bandung: Mizan, 1996.

TEOLOGIA, VOLUME 25, NOMOR 2, JULI-DESEMBER 2014 
